\title{
Transformations: New media art between communities and professional practice
}

\author{
Oliver Mag Gingrich \\ Art in Flux \\ London, UK \\ gingricho@bournemouth.ac.uk
}

\author{
Aphra Shemza \\ Art in Flux \\ London, UK \\ aphra@aphrashemza.com
}

\author{
Maria Almena \\ Art in Flux \\ London, UK \\ maria@kimatica.net
}

\begin{abstract}
Media Arts has long been regarded as a niche within the contemporary art discourse, secluded from the art market and from the public alike. As technology becomes more accessible, these former boundaries erode. While the art market slowly starts to embrace new media artists, local communities show a renewed interest in the power of technologically-facilitated art, due to its participatory nature. How do professional media artists make a living outside of the constraints of the contemporary art market? How can local communities and the public profit from media art?
\end{abstract}

Media art. Networks. Art in Flux. Community art. Community engagement.

\section{INTRODUCTION}

Over the last 4 years ART IN FLUX has provided a major platform for media artists in the UK. What started as a platform by artists for artists, turned into public-facing activities that involve the general public as much as local communities. In recent years, ART IN FLUX developed workshops that invited local residents in North Kensington to work together on a collaborative digital art piece in the project AYAH - Sign. ART IN FLUX orchestrated workshops with Stuart Batchelor that were shown at ACAVA's Maxilla Space, before they were offered to the general public at the V\&A Museum. This year, ART IN FLUX is on the cusp of developing a workshop series that draws from the experience of media arts practitioners, while applying the model of participatory practices to workshops.

This paper discusses the transformation of media arts from a niche genre to a key strand of contemporary art, as well as the educational potential of media arts for local communities.

\section{ART IN FLUX - A JOURNEY}

Media arts are often regarded as a parallel universe, offset from the classic, contemporary art market, with its own rules, methods, and societal fabric. In the case of contemporary media arts, two distinguishing characteristics are the absence of national institutions in the UK (Shemza, Gingrich \&

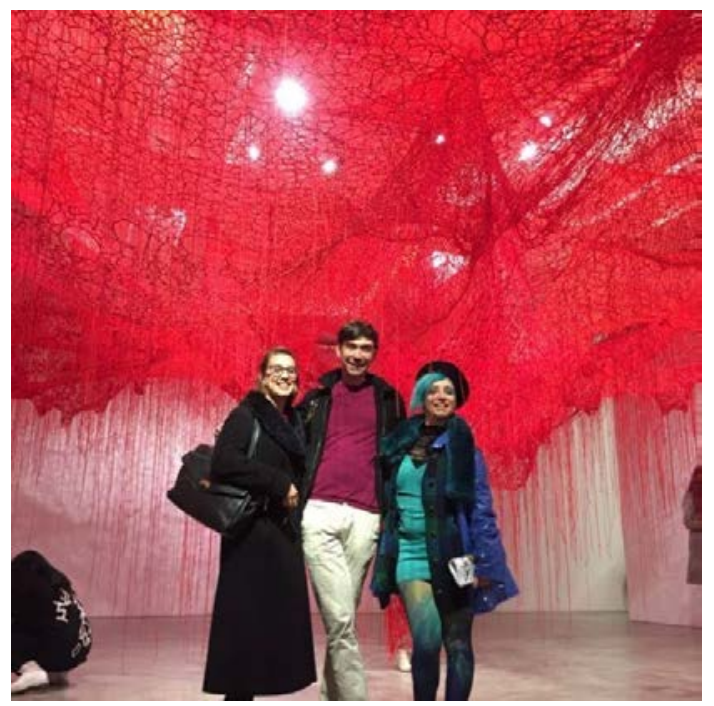

Figure 1: ART IN FLUX Team: Aphra Shemza, Oliver Mag Gingrich and Maria Almena (from left to right).

Almena 2019), as well as the relative neglect by traditional art markets in parts due to high installation and maintenance costs of media arts (Geer 2004). Due to recent commercial success of contemporary media artists (Marshmellow Laser Feast 2019, Teamlab 2019), this second trend seems to finally have come to a halt.

Art in Flux was founded by the three media artists Aphra Shemza, Maria Almena and Oliver Mag Gingrich because of an apparent need to compensate for the void of media art institutions. 
This almost total absence of media art institutions at the beginning of the new Millennium not only caused societal, communal and socio-economic withdrawal symptoms for a generation of media artists, it also resulted in relative invisibility of a whole genre. With the exception of a few notable exhibitions (V\&A 'Digital Design Weekend', Waterman's 'Technology is not neutral' and the Barbican's 'Digital Revolutions'), media arts operated in a vacuum predominantly filled by art fairs (Kinetica Art Fair) and Festivals (Future Everything, Abandon Normal Devices Festival).

ART IN FLUX (formerly known as FLUX Events) was founded in 2016 at the Lights of Soho Gallery at the heart of the bustling Soho art district, as a regular talks event for London's contemporary media arts scene. Responding to the need for media artists to exchange ideas, to discuss strategies, conceptual focus, and to gather mutual feedback, FLUX provided a forum to harness inner strength, to bridge the gap in the knowledge infrastructure, to provide information on funding opportunities, to invite peers to exhibitions, and most of all to exchange ideas. At Dalston Boys Club, regular FLUX gatherings saw more than 200 participants taking part in performances, demos, and discussions.

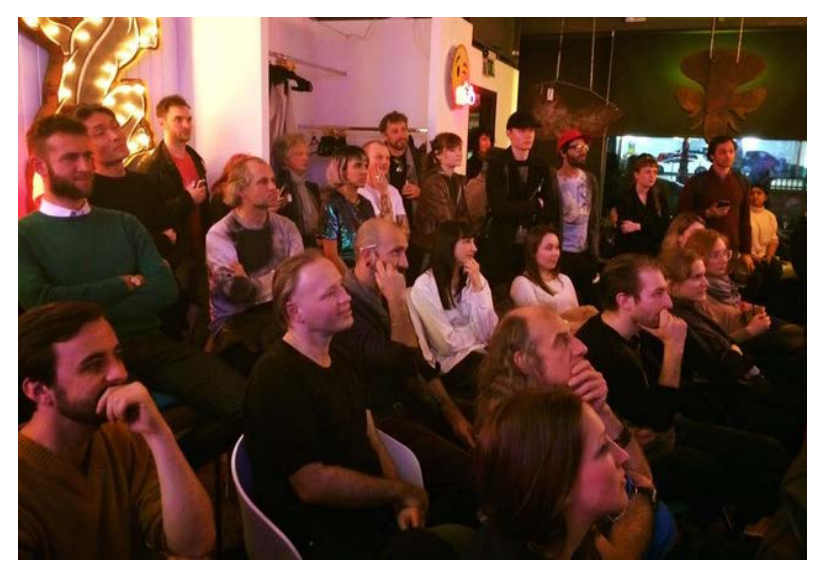

Figure 2: Simulacrum event curated by Oliver Mag Gringrich at Lights of Soho Gallery March 2017.

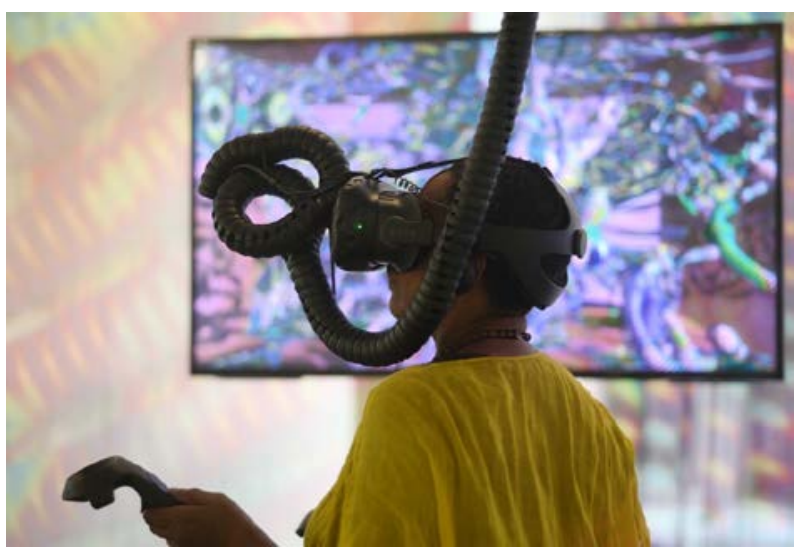

Figure 3: William Latham VR at Art in Flux.
This vital function of media art, to contribute to a wider discourse on the role of technology in society, soon became larger than the sum of its parts. A loose network of 30 media artists, grew into a larger family of more than 300 artists working across different genres, technologies and areas of interest. FLUX turned from an introspective, peerto-peer network into a community of minds. Receiving financial support by the Computer Arts Society, FLUX diversified its focus, from introspective towards an outward looking, publicfacing cultural offering to share these ideas with the wider public.

\section{ART IN FLUX - MEDIA ART FOR THE PUBLIC}

Following the foundation of a thriving peer-to peer artist network, through regular curated talks and events, a growing online presence and an eclectic social- media forum (Facebook), the time felt right to share our concepts, artistic practices and research with a wider public. ART IN FLUX - the first major exhibition, featured 14 media artists, more than 30 talks and two sold-out performance evenings.

The exhibition at London's Ugly Duck Festival featured some of the UK's most prolific media artists as well as talks by the Arts Council England, Computer Arts Society, the art platforms Zealous, ChromArt and many others. ART IN FLUX London - Experiments in Media Arts presented a dense array of media artists as a curated journey through some of the most relevant topics of media art practices of the decade. The exhibition can be seen as a nucleus for FLUX, becoming its namesake, but also changing the young network's paradigm from artist to artist, to a discourse that now involved the wider public.

\section{ART IN FLUX - NETWORKS}

As FLUX' public facing activities grew in scope, impact and visibility, the need to maintain both, internally orientated social events by artists for artists, and curated more public facing events, talks and exhibitions. With a new home at the London Library Club at St. Martin's Lane, ART IN FLUX began to host monthly socials for artists to present their work in progress to each other.

Orchestrated around a specific topic (Transformations, Posthumanism or Media Art and Health), these socials present an opportunity to come together, to provide vital feedback on each other's concepts, ideas and work, and to foster a culture of dialogue, exchange and mutual support among London's media art scene. The now annual Networks events, is a forum for art institutions to discuss media arts exchange across the UK. 
FLUX: Networks, our annual hosted event has brought together institutions such as the Computer Arts Society (chair Nick Lambert), EVA London (Graham Diprose), Centre for Performance Science (Ula Tymoszuk), Central Saint Martin's MA leader for Art and Science (Heather Barnett) and many others. The FLUX: Networks event went hand in hand with institutional collaborations the ART IN FLUX was spare-heading through its public talks program, its exhibitions and its workshop offering.

\section{FLUX: RADICAL ECOLOGY}

While orchestrating social forums for creative conversations, the three curators of FLUX, Aphra Shemza, Maria Almena and Oliver Mag. Gingrich decided to continue the practice of public engagement and outreach by hosting a larger curated talk each, with established media arts partners and institutions. The three talks centred around preeminent themes of wider societal importance: Aphra Shemza's talk 'Radical Ecology: Sustainable Media Art' brought together media artists Becky Lyons, Oskar Krajewski and Aphra Shemza as well as Tilly Hogrebe from Bowarts, the evening was curated by Julie's Bicycles Laura Pando and framed by an exhibition featuring Aphra Shemza's new pieces. Marking a new development 'Solutions for a Sustainable Media Arts Practice' funded by the Arts Council England, the evening resulted in vibrant discussions on sustainability in the media arts in front of a full house at media art exhibition space Ugly Duck.

\section{As curator and artist Aphra Shemza points out:}

\begin{abstract}
"This year has seen global demonstrations about the ecological climate crisis. Our generation is said to be the last that has the power to prevent catastrophic global warming, yet what can we do to make a difference?"
\end{abstract}

If we think of art as a tool with which artists are able to explore and raise questions about our human existence, the lives we lead and the society we inhabit, then media artists are right at the forefront of this discourse. They work with technology, innovation and look towards the future but are forced into a dialogue with our throwaway consumer culture as part of their process. Radical Ecology invites a number of key artists and thinkers exploring climate change, ecology, sustainable practice and conservation within their work.

The intensity and virulence of this public debate demonstrates its relevance, timeliness as well as the amount of emotional investment these public discourses can help to stimulate.

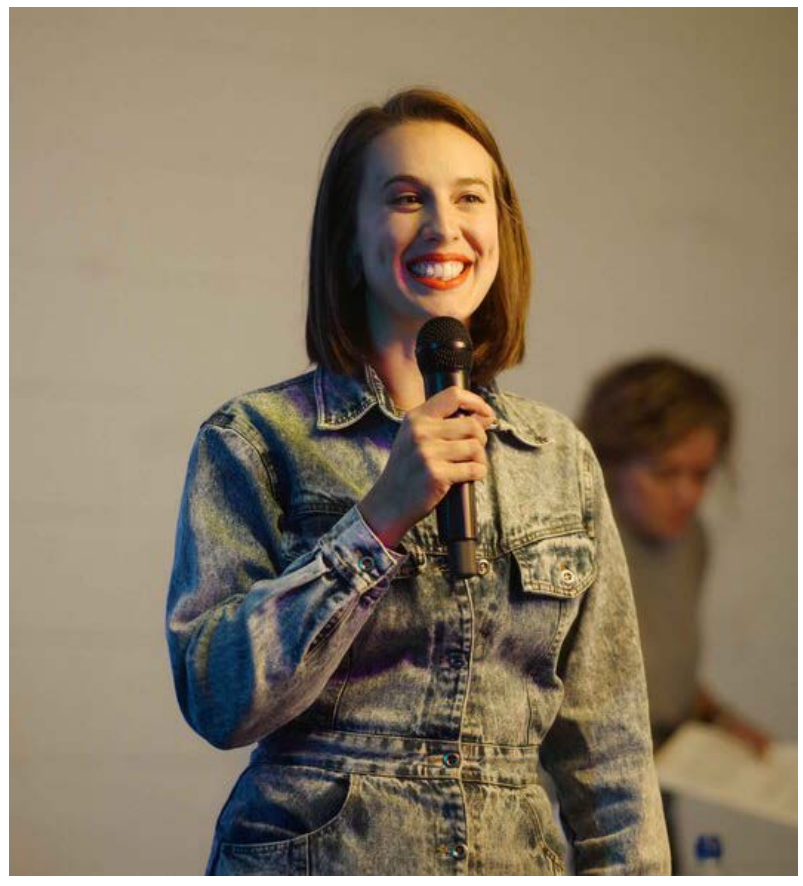

Figure 4: Aphra Shemza at Radical Ecology.

\section{FLUX: INVASIVE MEDIA}

Oliver Mag. Gingrich's talk 'Invasive Media: invited media artists Rachel Ara, Anna Troisi, Stacey Pitsillides and Lumen Prize winners Boredom Research to discuss how media artists tackle the invasiveness of data across all areas of our lives. The evening provided an overview of how different media artists work with data, how the change of agency from being subject of data to actively utilising data can change perception of data use, encouraging critical reflection and a deeper understanding of flows of data, intended use and motivations.

As data volumes are exploding, more data has been created in the past two years than in the entire previous history of humanity, Next year, $1,7 \mathrm{mb}$ of data will be created every second by every human being on the planet. Our accumulated digital universe of data will grow to about 44 zettabytes of data worldwide. Critical theorists like Douglas Rushkoff and George Monbiot point to a deep crisis in human appreciation of self, how much technology exposes, invades - how much we are in control of, or controlled by data.

Contemporary media artists not only highlight the role of technology in this context, they also subvert ideas of agency, in responding, and reflecting on invasive uses of data. The blurring of lines between data and human thinking goes far beyond the sphere of art and has penetrated all parts of our lives. The artist's role has always been to critically question these digital revolutions. FLUX: Invasive Data entices a discourse on art in the age of 
invasive data, investigating the penetration of big data across different spheres of our lives. The event at the Royal College of Art provided a forum for a public reflection on data use, data agency and data exploitation.

\section{FLUX: LEVITATIONS}

Artist and curator Maria Almena collaborated with London Laser and one of London's foremost art institutions Central Saint Martins on the groundbreaking 'FLUX: Levitations' an evening that explored the transformational potential of media arts practices. London LASER and Art in FLUX present an evening of immersive existential inquiry exploring how, in times of turbulent change, contemporary art practices can help take us into new realities with the intention of transforming our society. Our world is experiencing an enormous social, political, economic, environmental and technological change. Navigating this turbulence requires us to rethink the role that creative technologies should have in our contemporary society in order to address the deepest of human and planetary needs.

The evening consisted of talks, discussion and demos, asking how contemporary artists are using creative technologies to help take the right future steps. Looking particularly at immersive experiences, where art and technology are intertwined and embodied, we explore how transformative moments can inspire and influence future human behaviour, asking, if radical emerging technologies can help us to "levitate" into a better future? Maria Almena's FLUX: Levitation talk, organised in conjunction with Heather Barnett of London Laser, showed how artistic discourse can leave the confinements of discussions on methodology, and venture into a discourse on collective and individual effect, communitarian consequences and impact. After Maria Almena's introduction on the theme by sharing insights on her own art research with Kimatica studio, the event started with an immersive 360 sound performance by Christian Duka, intending to not only theoretically discuss this topic but also to offer a demo that could represent the type of transformative experiences we were exploring within the event. The evening featured talks by Dr Annahita Nehzami, Ari Peralta and Becky Stewart sharing their perspectives of what a transformative experience consists in.

Together these three curated evenings highlighted the potential of media arts discourse to instil a new form of public arena, a discourse framework for a multitude of ideas to strive, to evolve and to be critically questioned. These dialogues were held against the backdrop of highly active, hybrid multitudes of artistic media practice, displayed in a series of exhibitions involving local communities, media artists, arts institutions and the wider public.

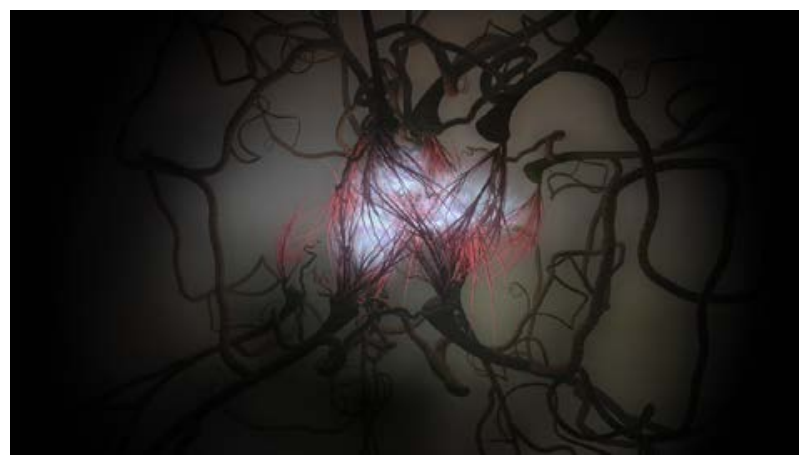

Figure 5: Boredom Research Dreams of Mice.

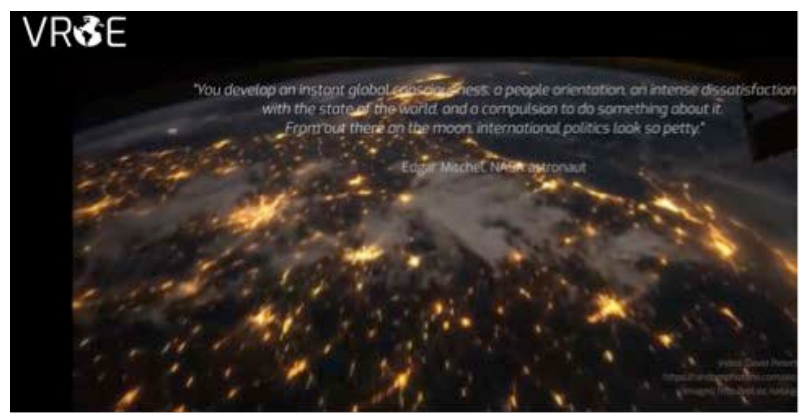

Figure 6: Annahita Nehzami: VR Overview Effect.

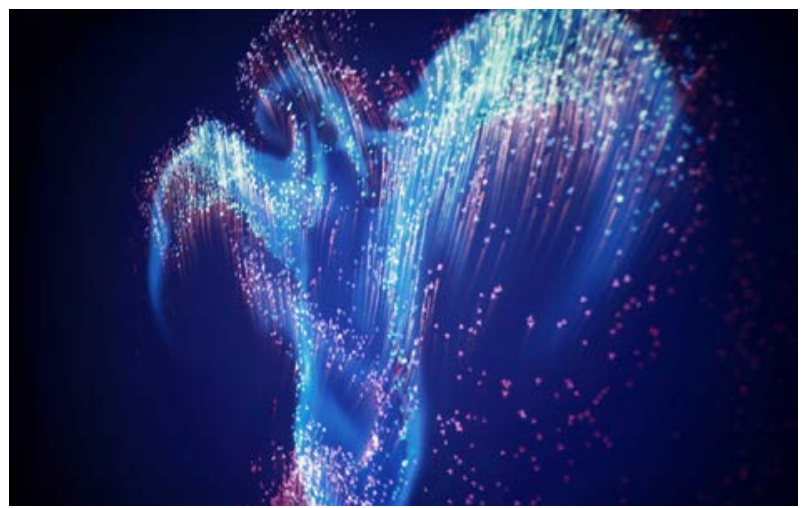

Figure 7: Kimatica's Relax and Release at Event Two, Royal College of Art.

\section{ART IN FLUX AT EVENT TWO}

To celebrate 50 years of the Computer Arts Society (CAS), CAS, EVA London, V\&A, Lumen, Royal College of Art and FLUX orchestrated Event Two. The exhibition ART IN FLUX at Event Two presented contemporary media arts practices by some of London's foremost media practitioners in a paralleled show that flanked the retrospective CAS 50 collection organised by Sean Clark.

Exhibited at the Royal College of Art, where 50 years prior the Computer Arts Society's seminal 'Event One' exhibition had taken place, this showcase was co-curated by RCA's Gareth 
Polmeer, Nick Lambert, Graham Diprose and the three FLUX co-founders Aphra Shemza, Maria Almena and Oliver Mag. Gingrich.

This landmark exhibition featured works by the Analema Group, Aphra Shemza, Andy Lomas, Cecilia Falkenstrom, Ernest Edmonds, Jon Weinel, Kimatica Studio, Mark Farid, Nicola Plant, Oliver Gingrich, Paul Friedlander, Rachel Ara and Stuart Batchelor as well as a moving image program with works by Karel Bata, Heather Barnett, Jake Elwes, Zarah Hussain and others. The cultural, historic success of Event Two was unprecedented, resulting in its adoption by the $V \& A$ for its annual Digital Design Weekend.

Ever since its inauguration by curator Irini Papadimitriou, the Victoria and Albert Museum's Digital Design weekend has turned into one of the year's most important digital art activities with thousands of Londoners visiting a multitude of activities, including demonstrations, workshops and interactive exhibitions. Event Two at the Digital Design Weekend was curated by Aphra Shemza, and symbolises ART IN FLUX's growing significance in the UK's digital art world.

\section{FLUX: TRANSFORMATIONS}

Hand in hand with FLUX's new focus on peer-topeer, public engagement and institutional networks, came a push to anchor media arts practices in communities, and to bridge the gap between media artists and the general public. Media arts are often perceived as aloof, elitist, and inaccessible, mainly due to their reliance on (often expensive) technology that might not be available to the general public.

ART IN FLUX first foray into community workshop was born out of a necessity. In the wake of the Grenfell fire tragedy, which cost 73 people their lives, ART IN FLUX in collaboration with artist Sara Choudhrey decided to host an exhibition and workshops on Islamic Digital Art practices in direct vicinity to the tragedy, to provide local residents with a forum for creative engagement. The resulting collaborative art piece created by local residents, in collaboration with Sara Choudhrey and Oliver Gingrich was subsequently exhibited at ACAVA's Maxilla space in conjunction with established media artists Zarah Hussain, Ben Johnson and Sara Choudhrey. The artwork AYAH - Sign created in workshops with local community members was projected opposite Grenfell tower to commemorate the tragedy and screened at the Portobello Film Festival that Summer. Supported by Arts Council England, RBKC Arts and ACAVA, AYAH - Sign was FLUX's first community arts workshop and is now nominated for a Prix Ars Electronica.

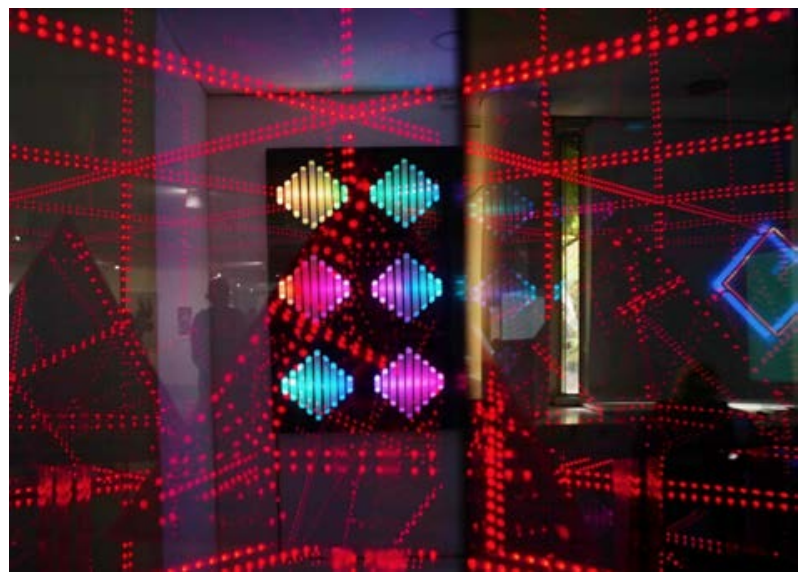

Figure 8: Aphra Shemza's Composition $X$ and Polyphonica at Event Two, Royal College of Art 2019.

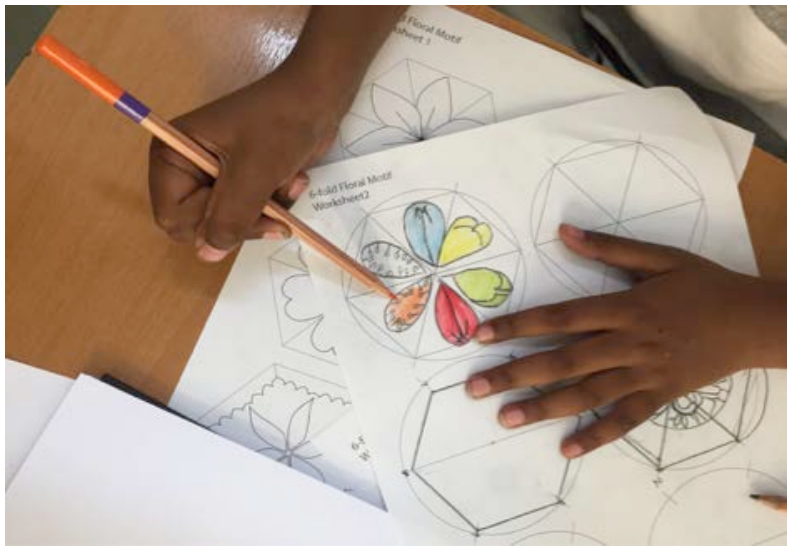

Figure 9: AYAH - Sign workshop w. Sara Choudhrey.

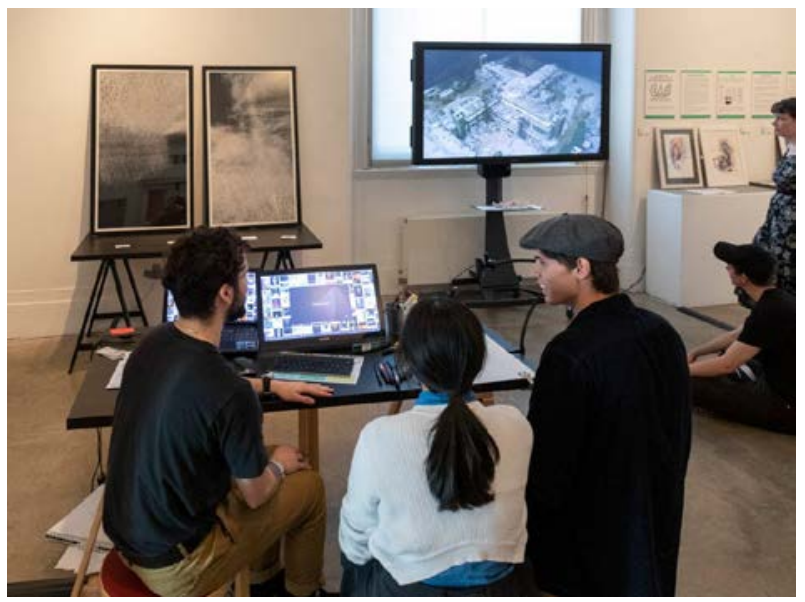

Figure 10: Stuart F. Batchelor's Digital Painting workshop.

A year later, ART IN FLUX organised Intelligent Matter, an exhibition and workshop by Stuart $F$ Batchelor and Oliver Mag Gingrich. Held at ACAVA's Maxilla Space during the second anniversary of the fire, the workshop invited local communities including schools and community groups to explore interactive art in workshops, demonstrations and a public facing talk. The school KAA Aldrige, directly affected by the fire, joined the 
brainwave art demonstrations by Oliver Gingrich. Stuart Batchelor's workshops were not only oversubscribed, his workshop format proved so successful that it was repeated both at Event Two and subsequently at the V\&A's Digital Design Weekend.

The success of these community outreach activities shows the potential of workshops to dismantle artificial barriers-to-entry and to break up the nimbus of an ivory tower of media art that has long persisted.

\section{OUTLOOK}

For 2020, ART IN FLUX decided to concentrate on these core strengths: A public facing exhibition at the new Computer Art Society head offices in Moorgate, will be framed by three larger curated talks and socials as well as our new online programming FLUX: Virtual.

ART IN FLUX is proud to have confirmed three major institutional partners for 2020: Our FLUX: Socials will continue to take place bi-monthly either virtually or at our new venue partner in central London. For our curated talks, we were able to confirm a new partnership with National Gallery X, a collaborative space between National Gallery, King's College and Google Lab. Three talks will be curated around intersections between Media Art and Health, Migration and Gender. These public facing talks will be taking place at the new National Gallery $X$ space opposite the National Gallery in central London, addressing a selected mix of people including creative industry experts, new media artists, academics and the general public.

In addition to our annual programming, we are looking forward to developing our workshop offering online as part of our FLUX: Virtual programming. FLUX: Virtual will take the core principles of ART IN FLUX to a global online community: Creative Conversations will echo our curated talks and feature dialogue between artists around a specific topic of cultural urgency. Due to the ongoing Covid-19 crisis, we have also started to take our FLUX Socials online, where we are hosting curated discussions on how artists can support each other in challenging times. Last but not least, we are looking to offer our workshops to a growing online audience, to share our knowledge on media arts practices with the wider London community. FLUX: Virtual will also see a new focus on mentorship, as well as a growing archive of publications, videos and documentations of our talks, our exhibitions and our FLUX: Virtual online presence.

Together, we are hoping that ART IN FLUX can continue this journey of creating networks, connecting artists, institutions and communities, to ensure our diverse audiences creatively enjoy and are inspired by the use of technology facilitated art. ART IN FLUX is ascribed to an understanding of media arts as an open art practice, open to everyone. We are interested in experiential, transformational media arts inquiries that bridge discrepancies, contributing to societal change in opening technology to everyone, not just as consumers, but as creators.

The future of ART IN FLUX will see multiple transformations, towards a rhizome of networks, institutional, personal, and between communities. We will continue to propagate social change through sustainable art practices and a responsible use of technology, to inspire future generations of art practitioners through vibrant discussions, mindbending artworks, while connecting between different voices within the arts.

\section{REFERENCES}

Boredom Research (2015) Dream of Mice [Film].

Computer Arts Society (1969) EVENT ONE Exhibition Catalogue. Royal College of Art. https://computer-arts-society.com/uploads/eventone-1969.pdf

Geere, C. (2004) New Media Art and the Gallery in the Digital Age. Tate Papers No 2, Autumn 2004.

Gingrich, O., Shemza, A. and Almena, M. (2018) FLUX Events: Current trends in contemporary media arts. In: EVA London 2018 (Electronic Visualisation and the Arts), 9-18 July 2018, British Computer Society. London: BCS, pp.211-212.

Hamilton, J. (2019) Event Two: The BCS Computer Arts Society. ITNOW, 61(4), Winter 2019, pp.2829.

Mason, C. (2008) A Computer in the Art Room: The Origins of British Computer Arts 1950 - 1980. Quiller Press.

Papadimitriou, I. (2018) Digital Futures. Exhibits at the EVA London 2018. EVA London 2018 (Electronic Visualisation and the Arts).

Polmeer, G. (2018) States of Being: Art and identity in digital space and time. EVA London 2018 (Electronic Visualisation and the Arts). 